\title{
Less charismatic animals are more likely to be "road killed": human attitudes towards small animals in Brazilian roads
}

\author{
Paulo C. M. D. Mesquita \\ Victor Mendes Lipinski \\ George Lucas Sá Polidoro
}

\author{
Laboratório de Herpetologia, Departamento de Biologia, Universidade Federal de Santa Maria \\ Avenida Roraima, 1000, CEP 97105-900, Santa Maria - RS, Brazil \\ * Corresponding author \\ paulocmdm@gmail.com
}

Submetido em 20/06/2014

Aceito para publicação em 29/12/2014

\section{Resumo}

Animais menos carismáticos são mais propensos a atropelamento: atitudes humanas em relação a pequenos animais nas estradas brasileiras. Estradas são fontes longas e intermitentes de diminuição da vida selvagem devido aos seus efeitos indiretos, como fragmentação de hábitat, ou seus efeitos diretos, como a constante mortalidade por atropelamentos. Assim, alguns estudos indicam que parte desses atropelamentos pode ser intencional e passível de ser evitada. Nós investigamos se diferentes grupos de pequenos animais apresentaram diferentes taxas de atropelamento e como o "carisma" afeta as chances de sobrevivência de um animal nas rodovias. Durante nosso experimento, nós quantificamos as taxas de atropelamento de modelos de aranhas, serpentes, pintos e folhas de árvore (controle) em três rodovias de diferentes volumes de tráfego. Constatamos que serpentes e aranhas foram consistentemente atropeladas com maior frequência que os pintos e as folhas. Também observamos que os pintos foram os únicos modelos resgatados pelos humanos. Concluímos que as chances de sobrevivência dos pintos é a maior entre os modelos testados e isso se deve ao valor carismático atribuído a eles pelos seres humanos, em comparação a serpentes e aranhas. Sugerimos a veiculação de campanhas na mídia que visem a aumentar a conscientização do público quanto à conservação da vida selvagem como uma ferramenta útil para solucionar o problema do atropelamento intencional de pequenos animais.

Palavras-chave: Aranhas; Conflitos com a vida selvagem; Conservação; Ecologia de estradas; Serpentes

\section{Abstract}

Roads are long and intermittent sources of wildlife loss due to their indirect effects, such as fragmentation of habitat, or their direct effects, such as constant mortality by run-over. Thus, some studies indicate that a portion of these run-over incidents may be intentional and could be avoided. We investigated whether various groups of small animals had different run-over rates and how "charisma" affects the survival chances of an animal on the roads. During our experiment, we quantified run-over rates for models of spiders, snakes, chicks, and tree leaves (control) on three roads with different traffic volumes. We found out that snakes and spiders were consistently ran over with a higher frequency than chicks and leaves. We also observed that chicks were the only models rescued by human beings. We concluded that the survival chances of chicks are the highest among 
the models tested and this is due to the charismatic value attributed to them by human beings, when compared to snakes and spiders. We suggest the broadcasting of campaigns in the media to increase public awareness regarding wildlife conservation as a useful tool to solve the problem of intentional run over of small animals.

Key words: Conflicts with wildlife; Conservation; Road ecology; Snakes; Spiders

\section{Introduction}

The relation between human beings and the environment is conflictive in several aspects, such as: urbanization, expansion of the agricultural boundaries, and cultural practices (e.g. hunting, religion, folklore), among others (HOARE, 2001; MICHALSKI et al., 2006; TREVES et al., 2006; CHAUHAN; PIRTA, 2010; DICKMAN, 2010; ALVES et al., 2012; LIU et al., 2013). At the epicenter of this scenario there are roads, since they are crucial for human geographic dispersal and have been identified, in many studies, as the cause of important impacts on the environment (FORMAN; ALEXANDER, 1998; TROMBULAK; FRISSELL, 2000; DISTEFANO, 2005; AMENT et al., 2008; VAN DER REE et al., 2011).

There is strong evidence that roads affect hydrology, vegetation structure, geomorphology, and wildlife populations in adjacent areas (TROMBULAK; FRISSELL, 2000; VAN DER REE et al., 2011). Population isolation, barriers for dispersion (MADER, 1984; LODÉ, 2000; EPPS et al., 2005), behavioral changes (ANDREWS et al., 2005; BOUCHARD et al., 2009; PARRIS et al., 2009), and increased mortality rates are the most studied problems regarding roads and the environment (FORMAN; ALEXANDER, 1998; HELS; BUCHWALD, 2001; HARTMANN et al., 2011).

Several field biologists observe during their expeditions that a portion of the dead fauna is found at less trafficked areas of roads, something which suggests that a number of run-over incidents may be intentional (ASHLEY et al., 2007; BECKMANN; SHINE, 2012). Although intuitive, there is still little evidence supporting such a suggestion (LANGLEY et al., 1989; ASHLEY et al., 2007).

Many studies quantified run-over incidents in various animal groups (TAYLOR; GOLDINGAY, 2004; RAO; GIRISH, 2007; MEEK, 2009; QUINTERO-
ÁNGEL et al., 2012). Moreover, few studies suggest that some animals are deliberately ran over and that certain populations are at higher risk (LANGLEY et al., 1989; LAURANCE et al., 2009).

Here, we study a potential intentionality factor that influences on run-over rate in various groups of small animals, in order to discuss possible measures to increase public awareness and knowledge.

\section{Material and Methods}

\section{Study area}

We studied three road stretches with different traffic volumes in Santa Maria, Rio Grande do Sul, Brazil. A federal highway (BR-287; W53 54'53.708”, S29 41'8.40"), a state highway (RS-287; W5340'52.82"; S29 $\left.42^{\prime} 19.09^{\prime \prime}\right)$, and the municipal road Norberto José Kipper (RS-511; W5342'15.07”, S2941'12.01”).

\section{Field experiment}

To test drivers' reaction to animals, we used realistic plastic models of spiders, snakes, and chicks, and a real tree leaf, aimed at serving as a control (Figure 1). We chose the tree leaf because this is a usual object on the road, i.e. it presumably does not change drivers' perception and behavior, thus run-over incidents involving the tree leaf were regarded as merely accidental.

We regarded as "valid vehicles" those travelling by themselves, around $250 \mathrm{~m}$ away from the next vehicle, using criteria adapted from Ashley et al. (2007), and all stretches chosen were straight lines, in order to allow viewing the models with no implication on the safety of drivers who intentionally steered their vehicles to hit the models. During daytime, each model was individually placed in less trafficked areas of roads (lane center and 
FIGURE 1: Materials used in the experiment. A) snake, B) chicks, C) spider, and D) tree leaf.

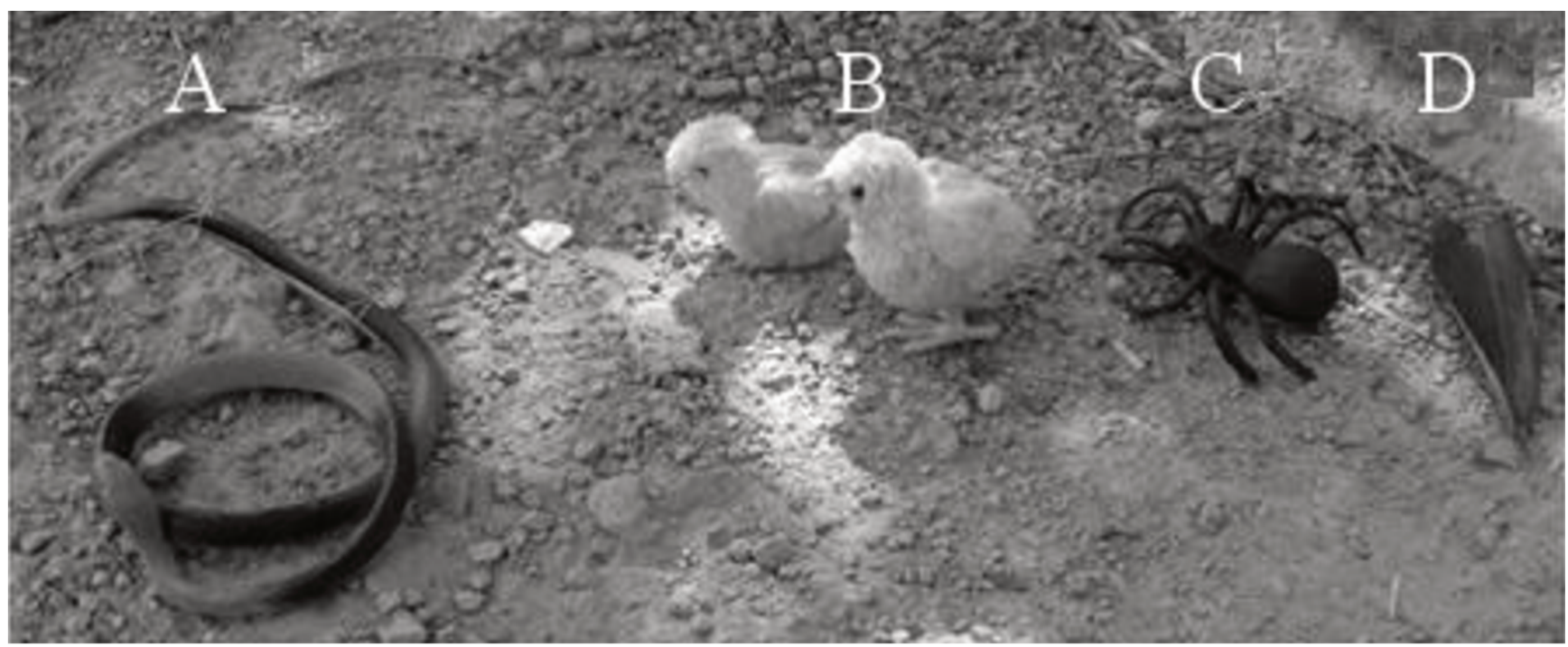

edge), so that it could be easily detected by the driver; we counted the first 200 "valid vehicles" to pass through the models, marking the results as "miss" or "hit". All models were replaced (if there was clear damage) or repositioned (if there was no clear damage) after a runover incident. Data was recorded on video to clarify any doubt a posteriori.

As measuring drivers' intention is presumably subjective and it was not possible to interview drivers after they passed through the models, we took into account the run-over rates of each model, without inferring with drivers' decisions.

\section{Analyses}

We compared run-over rates (number of vehicles/ number of run-over incidents) for each model between roads by means of a $\mathrm{G}$ test.

To identify which model had more run-over incidents, the results obtained in the field experiment for each treatment were compared by means of ANOVA and a post-hoc Tukey's paired test. For all analyses the differences were regarded as significant when $\mathrm{p} \leq 0.05$ by using the $R$ Sofiware (R DEVELOPMENT CORE TEAM, 2012).

\section{Results}

In the end of our experiment, we counted 2,400 "valid vehicles" (200 per model on each road). The experiment with all four models lasted 6 hours and 10 minutes at BR-286, 6 hours and 50 minutes at RS-287; and 10 hours at RS-511

We found that the run-over rates for each model (number of vehicles / number of run-over incidents) did not differ between roads (Spider: $\mathrm{G}=0.08, \mathrm{p}=0.95$; Snake: $\mathrm{G}=0.91, \mathrm{p}=0.63$; Chick: $\mathrm{G}=0.50, \mathrm{p}=0.78$; Leaf: $\mathrm{G}=0.40, \mathrm{p}=0.82$ ).

Overall, tree leaves (control) were hit by 15 vehicles $(2.5 \%)$, chicks were hit by 12 vehicles $(2.0 \%)$, snakes were hit by 29 vehicles $(4.83 \%)$, and spiders were hit by 31 vehicles $(5.17 \%)$. We registered rescue attempts only for chicks, $4(0.67 \%)$. We found that these runover rates differ between models (ANOVA F $=18.58$, $\mathrm{p}=0.01$ ) and results indicate that the spider and snake models were consistently ran over more frequently than leaves and chicks (Table 1). 
TABLE 1: Results of the post-hoc Tukey's paired test.

\begin{tabular}{lcc}
\hline \multicolumn{1}{c}{ Tested models } & $\mathbf{Q}$ & $(\boldsymbol{p})$ \\
\hline Leaf x Spider & 7.1554 & $<0.01$ \\
Leaf x Snake & 6.261 & $<0.01$ \\
Leaf x Chick & 1.3416 & 0.78 \\
Spider x Snake & 0.8944 & 0.92 \\
Spider x Chick & 8.4971 & $<0.01$ \\
Snake x Chick & 7.6026 & $<0.01$ \\
\hline
\end{tabular}

\section{Discussion}

In our experiment, we observed no significant difference regarding run-over rates between the roads. Even when comparing a slower and less used route, such as RS-511, with a route with heavier traffic volume, such as BR-286. These finding indicates that, in addition to accidental run-over incidents, a drivers' behavioral factor is also involved. Although Ashley et al. (2007) have recorded a lower run-over rate, they also identified a behavioral factor influencing on reptile run over. However, we already expected that the rate of accidents per unit time were different between roads, with higher rates on the road that has a heavier flow of vehicles, even considering the increased number of vehicles that were discarded for not meeting our inclusion criteria. This result is consistent with the suggestion by Fahrig et al. (1995) that the higher the volume and traffic speed, the greater the probability that an animal cannot complete the crossing, because this relation clearly increases the probability of accidental run-over incidents. Our results do not confirm the suggestion by Beckmann and Shine (2012) that on the slower roads intentional run-over incidents may be more frequent. It is likely that our inclusion criterion, i.e. "valid vehicles", reveals a clearer pattern than considering all vehicles.

The spider and snake models, i.e. animals culturally regarded as less charismatic (CZECH et al., 1998; DAVEY et al., 1998), were hit by vehicles more frequently than the tree leaf (control) and chicks. This result also highlights the existence of an intentionality degree among drivers who seem to deliberately run over small animals on the roads. This is consistent with the results reported by Knight (2008) and suggests that populations of less charismatic animals are at a higher risk on the roads because, in addition to accidental run-over incidents, they also face negative attitudes of drivers.

This behavior towards some animals was clearly observed during fieldwork, although we tested only drivers' reaction; the snake models were approached twice by pedestrians who tried to kill the "animal" by using stones and wood pieces.

In our study, we used chicks as representatives of a culturally charismatic animal (COURSEY, 1997). In most cases, these models were accidentally hit, since the run-over rates were lower than those of tree leaves (control) and they were also the only models with rescue attempts, when some drivers stopped their cars and turned back to remove animals from the area with potential risk. This indicates that rather "charismatic" animals may be at lower risk on the roads, as they are often actively avoided and occasionally rescued.

We also observed, with no quantitative data, that drivers frequently steered their vehicles to avoid hitting the chicks and they rarely tried to avoid snakes and spiders.

Our results indicate that, in addition to the risks of accidental run-over incidents, there is also an intentionality factor that increases the risk for "less charismatic" species and decreases the risk for more charismatic species.

The reasons for this negative attitude towards some animal groups may derive from a cultural prejudice against the species. We agree with the suggestions by Merckelbach et al. (1993) and Ceríaco (2012) that folklore and negative perceptions are effective predictors of persecution and anti-conservationist attitudes towards less charismatic animals.

A first step to promote conservation is broadcasting campaigns in the media to increase public awareness and knowledge; this is a cost-effective way to reach a high number of people with a relatively low investment (SALAFSKY et al., 2002).

Most public policy campaigns around the world regarding run-over incidents on the roads refers to large animals (HUIJSER et al., 2009), mainly aiming 
at traffic safety instead of conservation (CONOVER et al., 1995; PUTMAM, 1997; GARRETT; CONWAY, 1999; D'ANGELO et al., 2006; POKORNY, 2006; BISSONETTE; ROSA, 2012). Thus, small animals, which do not pose immediate risk to traffic safety, suffer an even more critical threat, since there seems to have no conservation campaigns to mitigate damage to small wildlife, especially when considering the rates of intentional run-over incidents.

We agree that, even with mitigation efforts, roads tend to be a persistent source of animal mortality in time and space, due to the proximity to natural areas and the constant flow of vehicles; they will invariably cause negative impacts on the fauna (TROMBULAK; FRISSELL, 2000). Aiming public campaigns to wildlife conservation, by increasing awareness and knowledge on the importance of the various animal species, constitutes a significant way to reduce the rate of intentional runover incidents and, therefore, minimize the negative effects of roads on animal populations.

We conclude that there is an intentionality factor in relation to run-over incidents involving less charismatic animals, something which leads us to suggest the broadcasting of campaigns in the media aimed at the conservation of wildlife.

\section{References}

ALVES, R. R. N.; PEREIRA FILHO, G. A.; DA SILVA, V. K.; SOUTO, W. M. S.; MENDONÇAS, L. E. T.; MONTENEGRO, P. F. G. P.; DE OLIVEIRA, A.W.; DA SILVA, V. W. L. A zoological catalogue of hunted reptiles in the semiarid region of Brazil. Journal of Ethnobiology and Ethnomedicine, London, v. 8, n. 1, p. 27, 2012.

AMENT, R.; ClEVENGER, A. P.; YU, O; HARDY, A. An assessment of road impacts on wildlife populations in US National Parks. Environmental Management, Heidelberg, v. 42, p. 480496, 2008.

ANDREWS, K. M.; GIBBONS, J. W.; REEDER, T. How do highways influence snake movement? Behavioral responses to roads and vehicles. Copeia, Lawrence, v. 4, p. 772-782, 2005.

ASHLEY, E. P.; KOSLOSKI, A.; PETRIE, S. A. Incidence of intentional vehicle-reptile collisions. Human Dimensions of Wildlife, Fort Collins, v. 12, p. 137-143, 2007.

BECKMANN, C.; SHINE, R. Do drivers intentionally target wildlife on roads? Austral Ecology, Alice Springs, v. 37, p. 629632,2012
BISSONETTE, J. A.; ROSA, S. An evaluation of a mitigation strategy for deer-vehicle collisions. Wildlife Biology, Freiburg, v. 18, n. 4, p. 414-423, 2012.

BOUCHARD, J.; FORD, A. T.; EIGENBROD, F. E.; FAHRIG. L. Behavioral responses of northern leopard frogs (Rana pipiens) to roads and traffic: implications for population persistence. Ecology and Society, Wolfville, v. 14, n. 2, p. 23, 2009.

CERÍACO, L. M. P. Human attitudes towards herpetofauna: the influence of folklore and negative values on the conservation of amphibians and reptiles in Portugal. Journal of Ethnobiology and Ethnomedicine, London, v. 8, p. 8, 2012

CHAUHAN, A.; PIRTA, R. Public opinion regarding humanmonkey conflict in Shimla, Himachal Pradesh. Journal of Human Ecology, New Delhi, v. 30, n. 2, p. 105-109, 2010.

CONOVER, M. R.; PITT, W. C.; KESSLER, K. K.; DUBOW, T. J.; SANBORN, W. A. Review of human injuries, illnesses, and economic losses caused by wildlife in the United States. Wildlife Society Bulletin, Washington, v. 23, p. 407-414, 1995.

COURSEY, D. L. Revealed demand for a public good: evidence from endangered and threatened species. New York University Environmental Law Journal, New York, v. 6, p. 411-449, 1997.

CZECH, B.; KRAUSMAN, P. R.; BORKHARTARIA, R. Social construction, political power, and allocation of benefits to endangered species. Conservation Biology, San Francisco, v. 12, p. 1103-1112, 1998.

D’ANGELO, G. J.; D’ANGELO, J. G.; GALlAGHER, G. R.; OSBORN, D. A.; MILLER, K. V.; WARREN, R. J. Evaluation of wildlife warning reflectors for altering white-tailed deer behavior along roadways. Wildlife Society Bulletin, Washington, v. 34, p. 1175-1183, 2006.

DAVEY, G. C. L.; MCDONALD, A. S.; HIRISAVE, U.; PRABHU, G. G.; IWAWAKI, S.; JIM, C. I.; MERCKELBACH, H.; JONG, P. J.; LEJNY, P. W. L.; REIMANN, L. A cross national study of animal fears. Behaviour Research and Therapy, Amsterdam, v. 36, p. 735-750, 1998.

DICKMAN, A. Complexities of conflict: the importance of considering social factors for effectively resolving human-wildlife conflict. Animal Conservation, London, v. 13, n. 5, p. 458-466, 2010 .

DISTEFANO, E. Human-wildlife conflict worldwide: collection of case studies, analysis of management strategies and good practices. Vol. 1. Rome: Food and Agricultural Organization of the United Nations (FAO), 2005. 34 p.

EPPS, C. W.; PALSBØLL, P. J.; WEHAUSEN, J. D.; RODERICK, G. K.; RAMEY, R. R.; MCCULLOUGH, D. R. Highways block gene flow and cause a rapid decline in genetic diversity of desert bighorn sheep. Ecology Letters, Montpellier, v. 8, n. 10, p. 10291038, 2005.

FAHRIG, L.; PEDLAR, J. H.; POPE, S. E.; TAYLOR, P. D.; WEGNER, J. F. Effect of road traffic on amphibian density. Biological Conservation, Boston, v. 73, p. 177-182, 1995.

FORMAN, R. T.; ALEXANDER, L. E. Roads and their major ecological effects. Annual Review of Ecology and Systematics, Palo Alto, v. 29, p. 207-231, 1998.

GARRETT, L. C.; CONWAY, G. A. Characteristics of moosevehicle collisions in Anchorage, Alaska, 1991-1995. Journal of Safety Research, Amsterdam, v. 30, n. 4, p. 219-223, 1999. 
HARTMANN, P. A.; HARTMANN, M. T.; MARTINS, M. Snake road mortality in a protected area in the Atlantic Forest of southeastern Brazil. South American Journal of Herpetology, São Paulo, v. 6, p. 35-42, 2011.

HELS, T.; BUCHWALD, E. The effect of road kills on amphibian populations. Biological Conservation, Boston, v. 99, n. 3, p. 331340, 2001.

HOARE, R. Determinants of human-elephant conflict in a land-use mosaic. Journal of Applied Ecology, London, v. 36, n. 5, p. 689700, 2001.

HUIJSER, M. P.; DUFFIELD, J. W.; CLEVENGER, A. P.; AMENT, R. J.; MCGOWEN, P. T. Cost-benefit analyses of mitigation measures aimed at reducing collisions with large ungulates in the United States and Canada; a decision support tool. Ecology and Society, Wolfville, v. 14, n. 2, p. 15, 2009.

KNIGHT, A. J. Bats, snakes and spiders, Oh my! How aesthetic and negativistic attitudes, and other concepts predict support for species protection. Journal of Environmental Psychology, New York, v. 28, n. 1, p. 94-103, 2008.

LANGLEY, W. M.; LIPPS, H. W.; THEIS, J. F. Responses of Kansas motorists to snake models on a rural highway. Transactions of the Kansas Academy of Science, Lawrence, v. 92, p. 43-48, 1989.

LAURANCE, W. F.; GOOSEM, M.; LAURANCE, S. G. Impacts of roads and linear clearings on tropical forests. Trends in Ecology \& Evolution, London, v. 24, n. 12, p. 659-669, 2009.

LIU, X.; MCGARRITY, M. E.; BAI, C.; KE, Z.; LI, Y. Ecological knowledge reduces religious release of invasive species. Ecosphere, Ithaca, v, 4, n. 2, art21, 2013.

LODÉ, T. Effect of a motorway on mortality and isolation of wildlife populations. AMBIO: A Journal of the Human Environment, Washington, v. 29, n. 3, p. 163-166, 2000.

MADER, H. J. Animal habitat isolation by roads and agricultural fields. Biological Conservation, Boston, v. 29, n. 1, p. 81-96, 1984.

MEEK, R. Patterns of reptile road-kills in the Vendée region of Western France. Herpetological Journal, Montrose, v. 19, n. 3, p. 135-142, 2009.

MERCKELBACH, H.; DE JONG, P. J.; ARNTZ, A.; SCHOUTEN, E. The role of evaluative learning and disgust sensitivity in the etiology and treatment of spider phobia. Advances in Behaviour Research and Therapy, Amsterdam, v. 15, p. 243-255, 1993.
MICHALSKI, M. F.; BOULHOSA, M. R.; FARIA, M. A.; PERES, M. C. Human-wildlife conflicts in a fragmented Amazonian forest landscape: determinants of large felid depredation on livestock. Animal Conservation, London, v. 9, p. 179-188, 2006.

PARRIS, K. M.; VELIK-LORD, M.; NORTH, J. M. Frogs call at a higher pitch in traffic noise. Ecology and Society, Wolfville, v. 14, n. 1, p. 25, 2009.

POKORNY, B. Roe deer-vehicle collisions in Slovenia: situation, mitigation strategy and countermeasures. Veterinarski Arhiv, Zagreb, v. 76, p. 77-187, 2006.

PUTMAM, R. Deer and road traffic accidents: options for management. Journal of Environmental Management, New York, v. 51, n. 1, p. 43-57, 1997.

QUINTERO-ÁNGEL,A.; OSORIO-DOMINGUEZ, D.; VARGASSALINAS, F.; SAAVEDRA-RODRÍGUEZ, C. A. Roadkill rate of snakes in a disturbed landscape of Central Andes of Colombia. Herpetology Notes, Pisa, v. 5, p. 99-105, 2012.

RAO, R. S. P.; GIRISH, M. S. Road kills: assessing insect casualties using flagship taxon. Current Science, Bangalore, v. 92, n. 6, p. 830-843, 2007.

R DEVELOPMENT CORE TEAM. R: a language and environment for statistical computing. Vienna: R Foundation for Statistical Computing, 2012. Disponível em: <http://www.R-project.org/>.

SALAFSKY, N.; MARGOLUIS, R.; REDFORD, K. H.; ROBINSON, J. G. Improving the practice of conservation: a conceptual framework and research agenda for conservation science. Conservation Biology, San Francisco, v. 16, n. 6, p. $1469-$ 1479, 2002.

TAYLOR, B. D.; GOLDINGAY, R. L. Wildlife road-kills on three major roads in north-eastern New South Wales. Wildlife Research, Collingwood, v. 31, n. 1, p. 83-91, 2004.

TREVES, A.; WALLACE, R. B.; NAUGHTON-TREVES, L.; MORALES, A. Co-managing human-wildlife conflicts: a review. Human Dimensions of Wildlife, Fort Collins, v. 11, n. 6, p. 383396, 2006.

TROMBULAK, S. C.; FRISSELL, C. A. Review of ecological effects of roads on terrestrial and aquatic communities. Conservation Biology, San Francisco, v. 14, p. 18-30, 2000.

VAN DER REE, R.; JAEGER, J. A.; VAN DER GRIFT, E. A.; CLEVENGER, A. P. Effects of roads and traffic on wildlife populations and landscape function: Road ecology is moving toward larger scales. Ecology and Society, Wolfville, v. 16, n. 1, p. 48-48, 2011. 